\title{
Quality of veterinary pharmaceuticals and their use by pastoralists in the Far North Region of Cameroon
}

\author{
Ronald Romuald B. Vougat Ngom ${ }^{1 *}$, Tiédja Tomdieu², Roland Ziébé ${ }^{2}$, Harquin Simplice Foyet ${ }^{1}$, Mark Moritz ${ }^{3}$, \\ Lazare Vondoư ${ }^{2}$, Dwayne E. Schrunk ${ }^{4}$, Paula M. Imerman ${ }^{4}$, Wilson K. Rumbeiha ${ }^{4}$ and Rebecca B. Garabed ${ }^{3}$
}

\begin{abstract}
This study evaluates the quality of the veterinary drugs most frequently used in the Far North Region of Cameroon and describes how pastoralists use them to treat their cattle herds. High-performance liquid chromatography was used to identify and quantify the active ingredients in the drugs (penicillin G, levamisole, oxytetracycline, diminazene diaceturate, vitamin A, and vitamin E acetate) and gas chromatography mass spectrometry to determine if organic chemical contaminants were present. The results showed that $69 \%$ of surveyed pastoralists used veterinary medicines to treat common illnesses. In addition, the most commonly used medications (procaine penicillin $\mathrm{G}$ and oxytetracycline) were used in a manner inconsistent with the recommended dosage, frequency, duration, and withdrawal period by $98 \%$ of the pastoralists. However, contrary to previous studies, the quality of the medications used by pastoralists was generally good. The poor compliance with recommended treatment protocols was much more prevalent than use of poor quality medications and presents a potential for treatment failure, drug resistance of animal pathogens, and harmful drug residues in the human food supply, all of which have potentially negative consequences for animal and human health.
\end{abstract}

Keywords: Dosage, Medicine, Oxytetracycline, Pastoralist, Penicillin, Veterinary pharmaceutical

\section{Introduction}

The Far North Region of Cameroon has the second highest cattle population in the country with about $38 \%$ of the total national cattle herd (Ziébé et al. 2005). In this region, where the rate of extreme poverty is the highest in the country (41\%), livestock production is one of the main activities and represents the second highest source of cash income to the rural populations after cotton (Ziébé et al. 2005; GESP 2009). To treat livestock diseases, pastoralists use a variety of veterinary medications that, generally, they administer themselves (Moritz et al. 2013; Tomdieu 2013; Vougat 2013). These veterinary medications are usually sold by untrained vendors in livestock markets.

Previous studies in Cameroon showed that $69 \%$ of veterinary drugs sold did not meet international quality

\footnotetext{
* Correspondence: romsonbey@yahoo.fr

${ }^{1}$ Department of Biological Sciences, Faculty of Sciences, University of Maroua, Maroua, Cameroon

Full list of author information is available at the end of the article
}

standards (Messomo 2006). Similarly, work done in 2001 in five regions of Cameroon on anthelmintics containing albendazole or levamisole and the trypanocidal drugs containing diminazene or ethidium (bromide or chloride) showed that the quality of $47 \%$ of the 34 samples collected in both official and informal markets were not up to international quality standards (Abiola 2001). The problem of low-quality veterinary medicines reaches beyond Cameroon as well. In Senegal, 67\% of veterinary medicinal products failed to meet regulatory standards. In this country, the oxytetracycline-based group of antibiotics had the highest level of non-conformity with standards (93\%) (Têko-Agbo et al. 2008). Research conducted in Benin, Togo, Mali, Mauritania, and Chad has also shown that veterinary medicines sold in the parallel (unofficial) market are of poorer quality (Abiola 2002a, b; Têko-Agbo et al. 2003; Abiola 2005). 
These studies highlight the potential for problems with veterinary medication quality in Cameroon but do not describe how these drugs are used by different pastoralists, which is another potential risk to animal and human health. Roderick et al. (2000), for example, showed that Maasai pastoralists generally overdose their cattle when treating tsetse flies and trypanosomosis. Roderick et al. (2000) also noted that in most cases, farmers gave a single injection rather than a course of treatment, and trypanocides and antibiotics were mixed together before injection. The consequences of misuse of medications could be simple failure of the treatment, resulting in economic loss, or if pervasive could result in drug resistance in pathogens. The problem of improper use of drugs in veterinary medicine is amplified by their use in food-producing animals. In this case, there is the possibility that minimal quantities of drugs and their metabolites (residues) which remain in edible tissues or in animal products (meat, milk) induce certain harmful effects in consumers of such food (Sanders 2007). Considering that most pastoralist families in our study area consume milk from their animals daily, the impact of the improper use of veterinary medicines for human health is highest in this population.

The aim of this study was to describe the use of medications by pastoralists in the Far North Region of Cameroon using the case of treatment of a common and recognizable disease and to determine the quality of medications they use for such treatment. We have chosen to use foot-andmouth disease (FMD) as a focal disease because it is prevalent (over 70\% seroprevalence using a conservative estimate from Ludi et al. (2016)) and easily recognized by cattle herders of this region (recognizable signs noted in Grubman and Baxt (2004) and Spickler et al. (2010)), so herders can easily answer questions about treating the disease from memory. While FMD is a viral disease with no known effective treatment, our previous work with this population (Ludi et al. 2016) informed us that pastoralists treat their cattle for this disease and report success in many cases, perhaps due to the mild, self-limiting nature of the disease in partially immune adults and perhaps due to effective treatment of secondary and concurrent infections/infestations.

In addition to describing medication use by pastoralists, we sampled the most commonly used medications and tested their chemical composition to determine whether pastoralists self-select higher quality medications than what has been noted previously.

\section{Study area}

The study was conducted in the Far North Region of Cameroon, a region that lies between $9^{\circ}$ and $13^{\circ}$ north and $13^{\circ}$ and $16^{\circ}$ east with a total area of approximately $34,263 \mathrm{~km}^{2}$ (NSI 2010; MIDIMA 2011). The biophysical characteristics of this study area are as described in our previous paper (Vougat et al. 2015). Generally, the region is dry with a rainy season from June to November. A substantial portion of pastoralists are based in villages (agro-pastoralist), while a minority move their herds seasonally (transhumant) to exploit new vegetation that grows as waters recede in the floodplain of the Logone River in the northeast of the region. While sedentary pastoralists often raise crops or fish, mobile pastoralists live almost exclusively from their herds. The primary livestock species in the region is cattle.

In general, agro-pastoralist herds are smaller but more numerous and may contain sheep, goats, poultry, and cattle, while the transhumant herds are larger but fewer in number. The transhumant pastoralists in the region belong to different Arab and FulBe groups and are highly specialized in animal production. In most groups, the key animal is cattle. They also keep small ruminants (sheep and goats) and chickens to cover small expenses and donkeys and horses for transport. These two production systems share pasture and water resources as well as trade networks (markets) and veterinary services.

In this region, infectious animal diseases limit cattle productivity and production (Yaya 2008). The veterinary infrastructure is extensive, as there are currently 145 Zootechnical and Veterinary Centers, 43 vaccination sites, and 19 livestock markets in the Far North Region. A Zootechnical and Veterinary Center is a field office of the Ministry of Livestock, Fisheries and Animal Industries (MINEPIA) in charge of doing annual mandated vaccinations and veterinary health controls at livestock markets and along transhumance and trade routes. Though an administrative structure and health technicians are present, there are only three veterinary doctors in the region (Report of Far North Regional delegation of MINEPIA 2014-unpublished). The veterinary services in the region are primarily concerned with annual mandated vaccination campaigns against contagious bovine pleuropneumonia, hemorrhagic septicemia, blackleg, and anthrax and veterinary health controls at livestock markets and along transhumance and trade routes. For example, in 2013, 235,920 cattle were vaccinated against contagious bovine pleuropneumonia, 450,110 against blackleg, and 450,110 against lumpy skin disease (Report of Far North Regional delegation of MINEPIA 2014-unpublished). However, other infectious diseases, like FMD, are endemic in the region, and the rates of infection are high (Ludi et al. 2016). At the time of our study, there were no vaccines available in the region for FMD.

\section{Methods}

\section{Sampling of pastoralists}

We conducted a survey that included questions relating to epidemiology of FMD, treatments used in cases of FMD, 
and how herders use veterinary pharmaceutical medicines to treat FMD. We administered surveys to two different groups: transhumant pastoralists who move with their herds and family year-round and agro-pastoralists who combine cotton farming with pastoralism and keep their animals in one general area during the year. Henceforth, the two groups will be called 'transhumant pastoralists' and 'agro-pastoralists', respectively.

Transhumant pastoralists were selected from a database which contained names of camp leaders of the Far North Region of Cameroon available at the Centre d'Appui à la Recherche et au Pastoralisme (CARPA), Maroua (Moritz et al. 2013). This database consisted of 157 names of camp leaders in alphabetical order. Twelve (12) camp leaders were chosen using a systematic sampling (sampling interval of 13) to give us a sample size of about $8 \%$ of camps. In each camp, we surveyed the camp leader and arbitrarily chose two additional pastoralists to survey. So in each camp, three transhumant pastoralists were interviewed: the camp leader and two others. A total of 36 transhumant pastoralists were interviewed. Given the timing of the survey, the majority of transhumant pastoralists were found in the Diamare and the Logone Floodplain (Figure 1).

Concerning agro-pastoralists, the study focused on pastoralists who used cattle for cultivating cotton. The agro-pastoralists concerned were those who inhabited the administrative subdivisions named Mayo-Sava, Diamaré, and Mayo-Kani (Figure 1). These three subdivisions were chosen for the following reasons: the Mayo-Sava subdivision borders Nigeria which is the country that provides the majority of French-speaking African countries with veterinary medications (Messomo 2006); the Diamaré subdivision covers Maroua, which is the biggest city of the region and the place where a preliminary investigation showed that $50 \%$ of the veterinary pharmacies and offices of the Far North Region are situated (Tomdieu 2013); the Mayo-Kani subdivision borders the Republic of Chad and

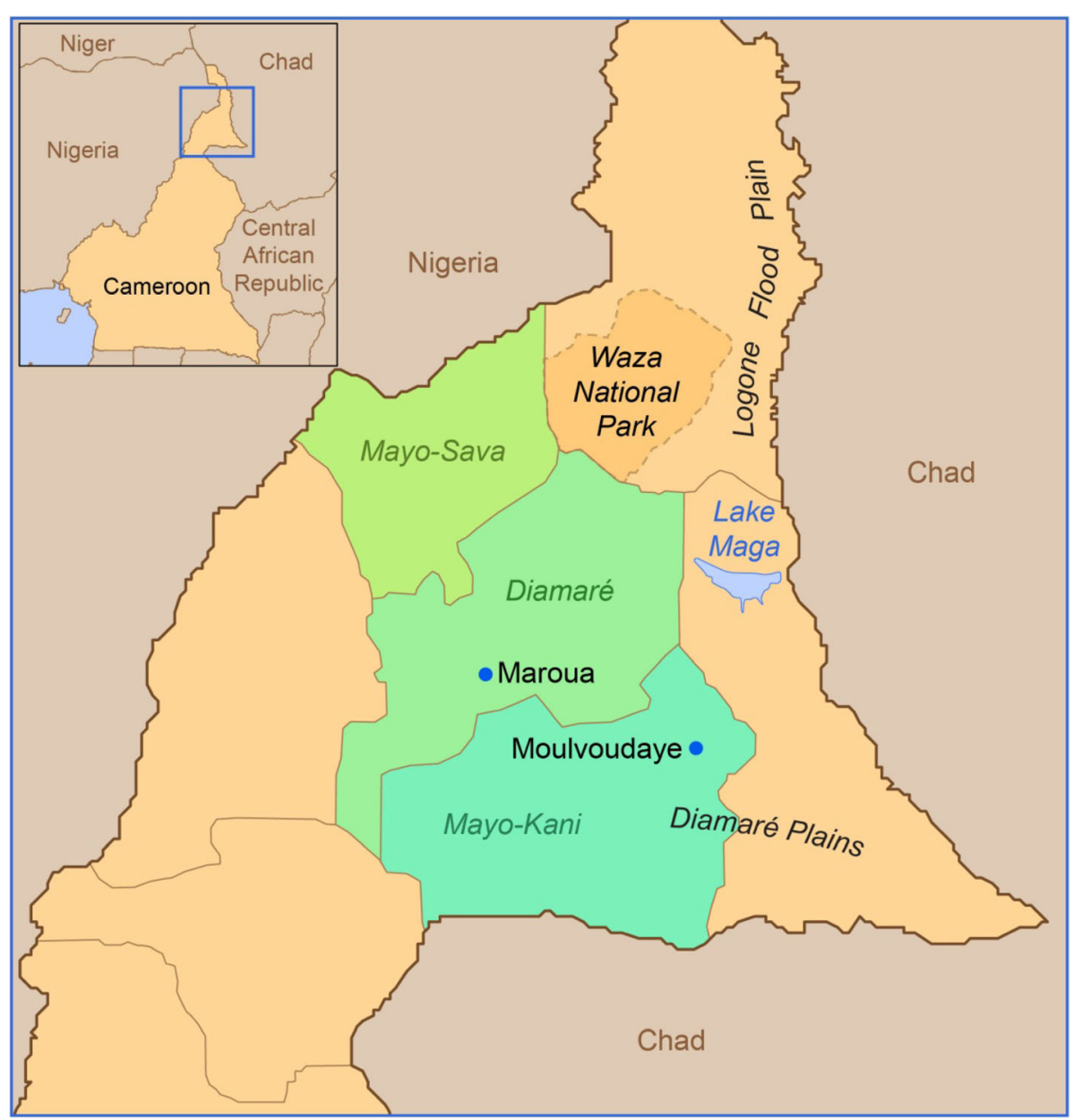

Figure 1 Study area in the Far North Region of Cameroon 
is an important zone of cattle farming (Chicoine 2007). The Société de Développement du Coton (SODECOTON) keeps a list of agro-pastoralists in these subdivisions from which 289 herders were chosen randomly and interviewed. The breakdown of the composition of these herders was as follows: 98 herders from Mayo-Sava subdivision, 88 from Diamaré subdivision, and 103 from Mayo-Kani subdivision. This part of the survey took place in 54 villages, which contained 3,290 agro-pastoralists according to the records of SODECOTON, giving us a sample fraction of approximately $9 \%$.

A total of 325 cattle herders were surveyed in this study, and interpreters assisted with administering the surveys in the native languages of the participants: Fulfulde, Arab Shuwa, Moundang, Mandara, Mafa, Kanuri, Guiziga, Mufu,Toupouri, Mada, Zoulgo, Kourgui, Bornoi, and Musgum. Interviews were spread out over a period of eight months from September 2011 to April 2012.

\section{Sampling of veterinary medications - drug quality}

Samples of veterinary medications for quality testing were purchased in livestock markets based on the frequency of use by pastoralists and other considerations that we detail here. We took into consideration the reported frequency of use of these drugs for controlling FMD, as well as the availability of the drugs in the Far North Region of Cameroon. First, we visited 34 of 95 (36\%) drug vendors identified in the Far North Region and assembled a list of 375 available medications (Additional file 1). Information on the active ingredients and manufacturers were collected from the labels, and the medications were broadly classified (e.g. antibiotic, anti-parasitic, trypanocide). During our surveys of pastoralists, we asked them to list all the medications that they used to treat FMD and provide details about names, colour of bottle and label, consistency of product (if the drug was liquid or solid), and colour of product. We took some example bottles with us during the surveys and also asked pastoralists to provide the bottle or package that they used, if it was available. If a specific product was identified, we recorded that. If the specific product could not be determined, the general medication was listed (e.g. oxytetracycline). These drugs were then ranked according to the frequency of use by transhumant pastoralists and agro-pastoralists. The top five drugs of the list were then purchased from the markets where the pastoralists reported purchasing them. If a general medication was listed, the two or three most common brands and formulations were purchased (Figure 2). In addition, due to logistical constraints, we had to purchase the medications prior to the completion of the surveys for agro-pastoralists, so two medications that were commonly identified by these herders (albendazole and ivermectin) were not purchased because they were not common in the lists at the time of purchasing. Three samples of each drug were purchased from different types of vendors who are described below Figure 3 .

The purchase consisted of the payment for drugs in cash in two livestock markets in the region (Maroua and Moulvoudaye). Just before our study, some groups, reportedly, had come through the region and seized counterfeit drugs, so the drug vendors were
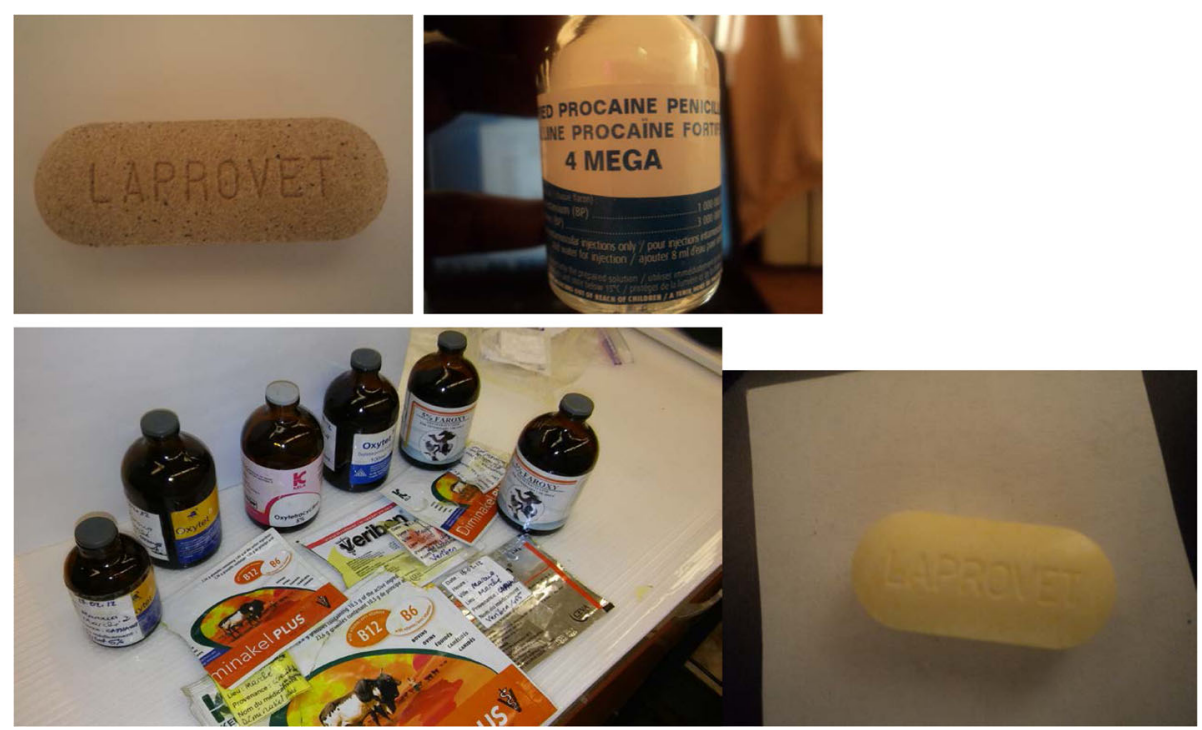

Figure $\mathbf{2}$ Some of the veterinary medicines used by pastoralists 


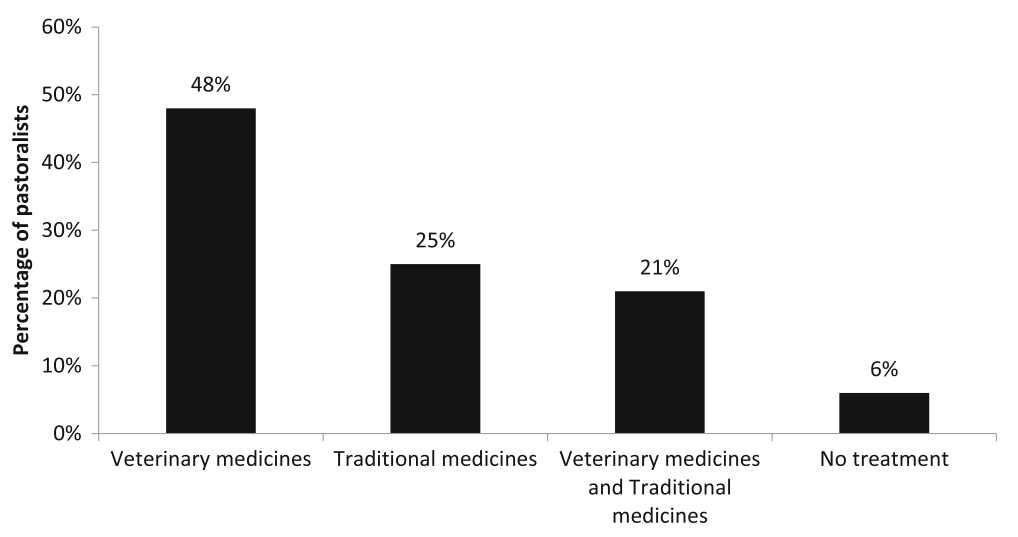

Figure 3 Types of medications used to treat FMD

leery of outsiders asking about veterinary drugs. Thus, in order to not attract attention, the purchases were made discreetly by local pastoralists. The veterinary medications were purchased from three main groups of vendors and in each market; specific vendors from whom we bought the drugs were selected arbitrarily.

The first group of vendors was those who have been trained as veterinary nurses and who generally sell in front of the office of the Delegation of MINEPIA adjacent to the markets. The majority of these vendors are veterinary officers. The second group consisted of vendors located inside the livestock markets. These vendors do not have any formal training in animal health. The third group of vendors included large brickand-mortar pharmacies and the Common Initiative Group (GIC) in the city of Maroua. The third group is considered by pastoralists to have medicines that are both more expensive and of higher quality. These three groups of vendors receive their medications from different supply chains, which might influence the quality of the drugs. If possible, a sample of the same drug was purchased from each of the three vendor types.

The purchased samples were sealed in a polystyrene packaging, labelled on a card designed for this purpose, and then securely hand carried to the Veterinary Diagnostic Laboratory at Iowa State University in Ames (USA) where they were analysed within the packagespecified expiration dates. Details of the chemical analysis methods used to quantify the contents of the medications can be found in Additional file 1 .

\section{Survey of medication use}

To evaluate the use of the veterinary medicines by the pastoralists, we asked for exactly how much of each medication had been used and for what size of cattle, how often, and for how many days during the most recent outbreaks of FMD. Generally, pastoralists indicated that cattle less than 2 years old and weighing less than $200 \mathrm{~kg}$ were considered small while bigger cattle were greater than 2 years old and $200 \mathrm{~kg}$. We also asked if pastoralists and their families refrained from drinking milk from treated animals or would wait to slaughter and consume a treated animal and for how long. For each active ingredient, we evaluated the dosage of the most common formulation because, in general, the pastoralists used several drugs that had the same active ingredient (for example Oxy $5 \%{ }^{\circ}$, Faroxy $5 \%$, and Oxytet ${ }^{5 \odot}$ ). In this survey, the assessment of the veterinary drug usage was restricted to four factors: the dose of administration, the frequency of medicine administration, the duration of treatment, and the withholding time before meat and milk from the animal were consumed. The label instructions of Fortified Procaine Penicillin ${ }^{\circ}$ indicated that this drug should be administrated once per day with the dose of $1 \mathrm{ml} / 15$ $\mathrm{kg} /$ day for a duration varying between 3 and 5 days. A withholding time of 14 days is recommended. For Oxytet ${ }^{5 \circ}$, the labelled dosage was once per day with the dose of 1 to $2 \mathrm{ml} / 10 \mathrm{~kg}$ for 3 to 5 days. The recommended withholding time was 14 days. Thus, we calculated that the maximum volumes that are recommended for cattle for Fortified Procaine Penicillin ${ }^{\circ}$ are $13.3 \mathrm{ml}$ (maximum weight of small cattle $(200 \mathrm{~kg}) \times$ dose $(1 \mathrm{ml} / 15 \mathrm{~kg}))$ and $33.33 \mathrm{ml}$ (maximum weight of big cattle in the region $(500 \mathrm{~kg}) \times$ dose $(1 \mathrm{ml} / 15 \mathrm{~kg}))$, respectively, for smaller and bigger cattle and $20 \mathrm{ml}$ and $100 \mathrm{ml}$ for Oxytet ${ }^{5 \circ}$.

This is found taking into consideration that there are few cattle in the region that weigh over $500 \mathrm{~kg}$. Indeed, Njoya et al. (1997) found that the maximum weight of a cattle in our study area was $400 \mathrm{~kg}$. 


\section{Data analysis}

The identification of the active ingredient in medications was performed by HPLC using the comparison of the retention time and the wavelength of the active ingredient in the tested product (finished product) with those of a reference standard.

The HPLC was also used to calculate the amount of active ingredient in samples according to a published formula (Messomo 2006; Têko-Agbo et al. 2008):

$$
\text { Result }=\frac{\text { Ses }}{\text { Sstd }} \times \frac{\text { Pes Standard }}{\text { Pes Test }} \times F \times T \times \mathrm{Mw}
$$

Result expressed in g/sample

Ses: peak area of the test solution

Sstd: peak area of the reference solution

Pes Standard: weight of the reference standard in $g$

Pes Test: weight of the test sample in $g$

$F$ : filution factor

$T$ : titer of the reference standard

Mw: average mass of the sample in $g$

For each veterinary drug sample $(n=3)$, analysis was done in triplicate (nine total times for one type of medicine) and a mean concentration of active ingredient was calculated. This was done to control for measurement error and sample variation. The calculated mean was compared to the concentration stated on the drug insert. For this, analysis of variance (one-way ANOVA) with multiple range test comparison (Duncan test) was implemented in Statgraphics version 3.0 software (Statpoint Technologies, Warrenton, VA). Differences with $p$ values $<0.05$ were considered to be statistically significant but do not necessarily represent biological significance.

The survey data were analysed with SPSS version 17.0 (SPSS Inc., Chicago, IL). This allowed us to calculate the descriptive statistics for all the variables evaluated.

\section{Results}

\section{Medication usage in cases of FMD}

Among the 289 agro-pastoralists, 38 of them had not treated their animals for FMD and 105 had only treated their cattle for FMD with traditional remedies (plant extracts or faith-based methods) or management changes (supportive care). Out of 146 agro-pastoralists who gave veterinary medications, $51 \%$ personally dosed their cattle, $37 \%$ invited a professional to give the medication, and $12 \%$ asked another layperson to give the medication. In contrast, all transhumant pastoralists who had treated their cattle for FMD had treated their animals themselves.

The types of medicines used by either group of pastoralists who had experienced FMD in their herds and could remember what medications were given are shown in Figure 3. Sixty-nine percent (69\%) (187 out of 271) of the pastoralists who had observed FMD in their herds used veterinary medications to treat their cattle when they
Table 1 Most common active ingredients in medications given to cattle for FMD

\begin{tabular}{llll}
\hline Active ingredient & $\begin{array}{l}\text { Agro-pastoralists } \\
(n=153), \%\end{array}$ & $\begin{array}{l}\text { Transhumant } \\
\text { pastoralists } \\
(n=29), \%\end{array}$ & Drug family \\
\hline${\text { Procain Penicillin } \mathrm{G}^{\mathrm{a}}}$ & 51 & 35 & Antibiotic \\
Oxytetracycline $^{\mathrm{a}}$ & 31 & 31 & Antibiotic \\
Diminazeneaceturate $^{\mathrm{a}}$ & 12 & 26 & Protozoocide \\
Albendazole & 16 & 0 & Anti-parasitic \\
${\text { Vitamins A and } \mathrm{E}^{\mathrm{a}}}$ & 15 & 0 & Vitamin \\
Ivermectin & 6 & 0 & Anti-parasitic \\
Levamisole $^{\text {a }}$ & 0 & 3 & Anti-parasitic \\
Isometamidium chloride & 0 & 3 & Protozoocide \\
Tylosin & 0 & 3 & Antibiotic \\
\hline
\end{tabular}

Indicates medications that were purchased for quality testing

were affected by this contagious disease. Only 6\% (16 of $271)$ did not do anything when FMD was observed in their cattle, while $25 \%$ (67 of 271) of them used only traditional medicine. There were significant differences in treatments chosen by transhumant pastoralists versus agro-pastoralists in that agro-pastoralists were more likely to use traditional medications than mobile pastoralists ( $50 \%$ versus $19 \%, p$ value $<0.001)$.

The active ingredients of medications used in FMD cases in the Far North of Cameroon are shown in Table 1. All cattle herders used penicillin $G$ and oxytetracycline most often, $48 \%$ and $31 \%$ of all cattle herders who used veterinary medications, respectively. Diminazene diaceturate, albendazole, and vitamins were used less often. There were a few differences in the choice of medications used by transhumant pastoralists versus agro-pastoralists, for example transhumant pastoralists did not use albendazole or vitamins $\mathrm{A}$ and $\mathrm{E}$.

Table 2 summarizes the results of usage of veterinary drugs by pastoralists. Proportions of the pastoralists following the recommended dosages of veterinary medications were generally low. In this study, among the 214 individuals who administered veterinary medications themselves, $86 \%$ followed label directions for amount/ dose of drugs for oxytetracycline and $57 \%$ followed the

Table 2 Usage of veterinary medicine by pastoralists $(n=214)$

\begin{tabular}{lll}
\hline & \multicolumn{2}{l}{ Veterinary medicines } \\
\hline Variable & Oxy5\% ${ }^{\circledR}$ & Fortified Procaine Penicillin \\
Use at labelled dose & $184(86 \%)$ & $122(57 \%)$ \\
Use at labelled frequency & $188(88 \%)$ & $83(39 \%)$ \\
Use for labelled duration & $39(18 \%)$ & $51(24 \%)$
\end{tabular}

Each number in the bracket represents the percentage of pastoralist 
directions for dosage of penicillin. In general, those who did not follow label recommendations administered more than the dose recommended.

Eighty-eight percent (88\%) followed label recommendations for the frequency of administration of oxytetracycline and 39\% followed the directions for frequency of administration of penicillin.

For duration of treatment, we found that, in general, label recommendations were not followed for either of the drugs used: $82 \%$ and $76 \%$ of pastoralists who treated their own animals did not follow this parameter for oxytetracycline and penicillin, respectively.

For penicillin, 53\% of respondents did not know there was a withholding time and $10 \%$ thought it was less than the recommended 14 days. All of the transhumant pastoralists continued to drink the milk of their cattle even when these animals were treated.

Only $2 \%$ of pastoralists followed all of the directions for dose, frequency, and duration of administration for oxytetracycline, and $1 \%$ followed all directions for penicillin.

\section{Quality of medications}

For the determination of active ingredients in drugs, the correlation coefficient of standard curves was $>0.995$ for all analytes. The retention times in minutes of the standards were $2.4,4.3,4.4,2.8,4.5,0.71$, and 3.65 for oxytetracycline, levamisole, procaine, penicillin $\mathrm{G}$, vitamin $\mathrm{E}$ acetate, vita$\min \mathrm{A}$, and diminazene diaceturate, respectively.
A summary of the results of the analysis of concentrations of active ingredients in different samples of drugs is shown in Table 3. For the most part (84.62\%), the concentrations of active ingredients were statistically different from what was listed on the medication label but were close to the expected concentrations. Thus, these statistical differences, most likely, are not clinically relevant. In addition, no significant differences in concentrations were observed between the medications obtained from the different types of vendors (veterinary officers, informal vendors, large pharmacies). However, the most significant finding of our chemical analysis of medication samples was that samples of Pemacain ${ }^{\circ}$ and Fortified Procaine Penicillin may have been lacking the procaine which was listed on their labels. The chromatograms of these samples show just the presence of penicillin $G$ and the water which was used to dissolve these powders (Figure 4a).

Figure $4 \mathrm{~b}$ presents the chromatograms of the standards of penicillin $\mathrm{G}$ and procaine (4.45 $\mathrm{min}$ ) and distilled water, respectively, all of which should be in the chromatograms for our samples (Figure 4a). However, the procaine peak is missing in Figure 4a. Also, the results of this study showed that all concentrations of vitamin A and vitamin E acetate in different samples of Boluvit ${ }^{\circ}$ were significantly lower than the concentrations listed on the labels (Table 2). As vitamins $\mathrm{A}$ and $\mathrm{E}$ degrade quite easily, this is probably related to poor storage of the medications at high ambient

Table 3 Concentrations in $\mu \mathrm{g} / \mathrm{g}$ (ppm) of active ingredients in different samples of veterinary medicines

\begin{tabular}{|c|c|c|c|c|c|}
\hline \multirow[t]{2}{*}{ Active ingredient } & \multirow[t]{2}{*}{ Veterinary drugs } & \multicolumn{4}{|l|}{ Samples } \\
\hline & & D1 & D2 & D3 & Concentration expected \\
\hline \multirow[t]{3}{*}{ Oxytetracycline } & Oxy $5 \%$ & $66,500 \pm 1,500^{*}$ & $71,700 \pm 600^{*}$ & $68,000 \pm 3,500^{*}$ & 50,000 \\
\hline & Oxytet ${ }^{5 \circledast}$ & $69,000 \pm 1,000^{*}$ & $65,500 \pm 500^{*}$ & $76,500 \pm 500^{*}$ & 50,000 \\
\hline & Faroxy $5 \%{ }^{\oplus}$ & $69,000 \pm 1,700^{*}$ & $66,700 \pm 4,200^{*}$ & $70,000 \pm 1,700^{*}$ & 50,000 \\
\hline \multirow[t]{2}{*}{ Levamisole } & Bolumisole $1^{\circledast}$ & $231,000 \pm 1,000^{*}$ & $220,000 \pm 4,600^{*}$ & $250,000 \pm 2,000$ & 250,000 \\
\hline & Bolumisole $3^{\oplus}$ & $585,200 \pm 2,800^{*}$ & $588,000 \pm 3,500^{*}$ & $628,500 \pm 500^{*}$ & 625,000 \\
\hline \multirow[t]{2}{*}{ Procaine } & Fortified Procaine Penicillin ${ }^{\oplus}$ & $0^{*}$ & $0^{*}$ & $0^{*}$ & 158,800 \\
\hline & Permacain ${ }^{\oplus}$ & $0^{*}$ & $0^{*}$ & $0^{*}$ & 158,800 \\
\hline \multirow[t]{2}{*}{ Penicillin G } & Fortified Procaine Penicillin ${ }^{\oplus}$ & $222,300 \pm 4,900^{*}$ & $287,700 \pm 5,500^{*}$ & $405,700 \pm 10,300^{*}$ & 299,600 \\
\hline & Permacain $^{\oplus}$ & $301,300 \pm 0.00$ & $242,000 \pm 0.00^{*}$ & $270,300 \pm 0.00^{*}$ & 296,300 \\
\hline Vitamin E acetate & Boluvit $^{\oplus}$ & $8,304.33 \pm 247.57^{*}$ & $9,435.77 \pm 478.26^{*}$ & $9,250.27 \pm 244.30^{*}$ & 18,000 \\
\hline Vitamin A & Boluvit $^{\oplus}$ & $379.38 \pm 7.15^{*}$ & $329.03 \pm 20.05^{*}$ & $336.93 \pm 0.75^{*}$ & 2,400 \\
\hline \multirow[t]{2}{*}{ Diminazene diaceturate } & Veriben $^{\circledast}$ & $336,000 \pm 1,000^{*}$ & $357,700 \pm 44,500^{*}$ & $376,700 \pm 6,000^{*}$ & 444,900 \\
\hline & Diminakel Plus ${ }^{\oplus}$ & $383,700 \pm 11,500^{*}$ & $405,700 \pm 17,000^{*}$ & $337,300 \pm 12,100^{*}$ & 444,900 \\
\hline
\end{tabular}

Values are mean \pm standard deviation of three experiments in triplicate; each sample of the same drug was purchased from three different vendor types: D1, D2, and D3. More details of how the expected concentration of the active ingredient was obtained can be found in the additional file

${ }^{*} p$ value $<0.05$ vs. standard concentration expected, which is the concentration written on the label of the medication 
a)
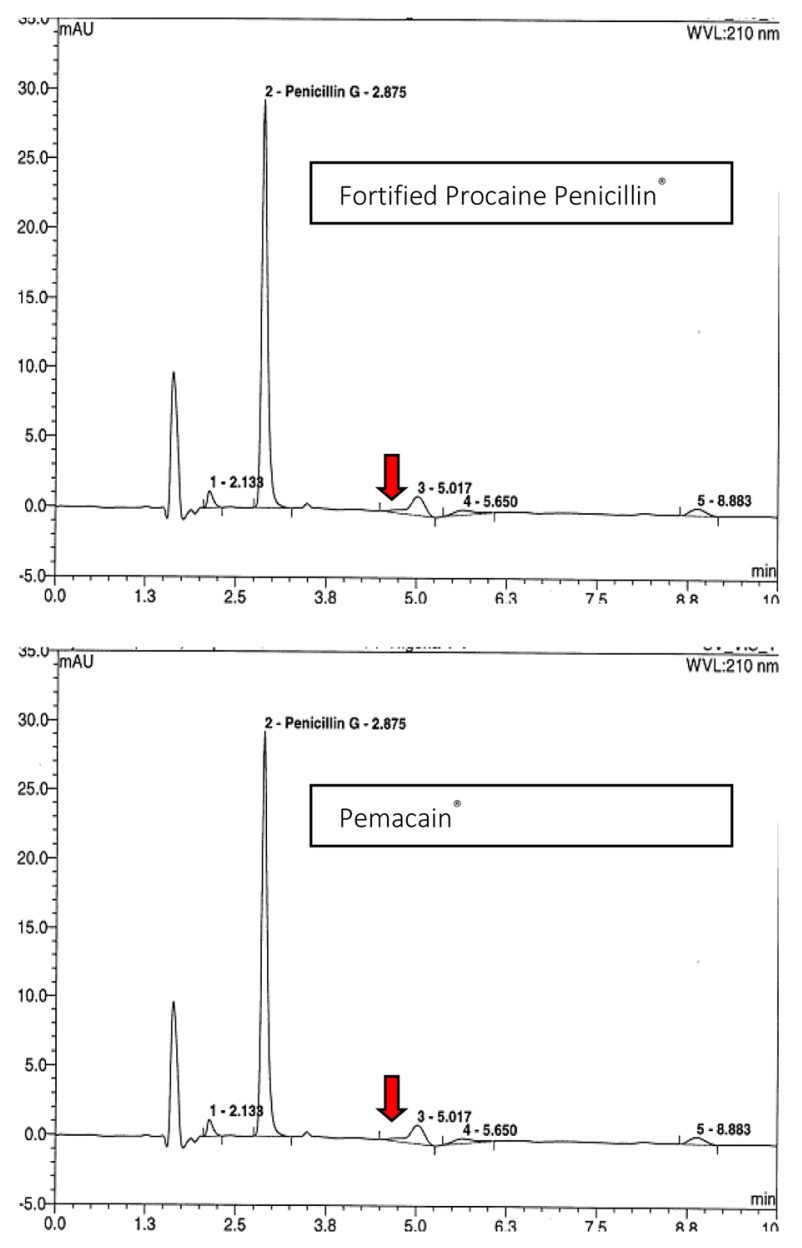

b)
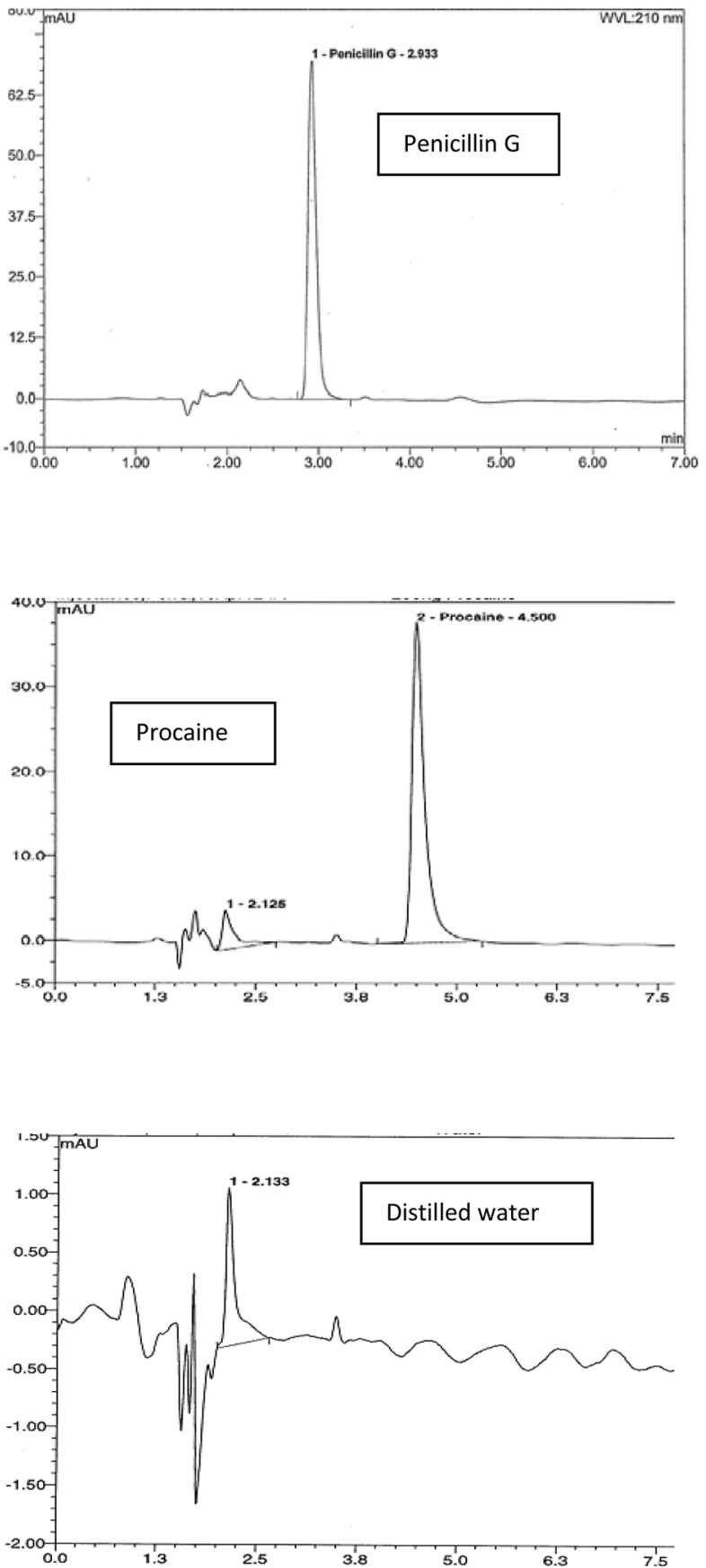

Figure 4 a Chromatograms of samples of procaine penicillin showing no procaine. Arrows highlight where procaine should be found. $\mathbf{b}$ Chromatograms of standards for penicillin $\mathrm{G}$, procaine, and water 


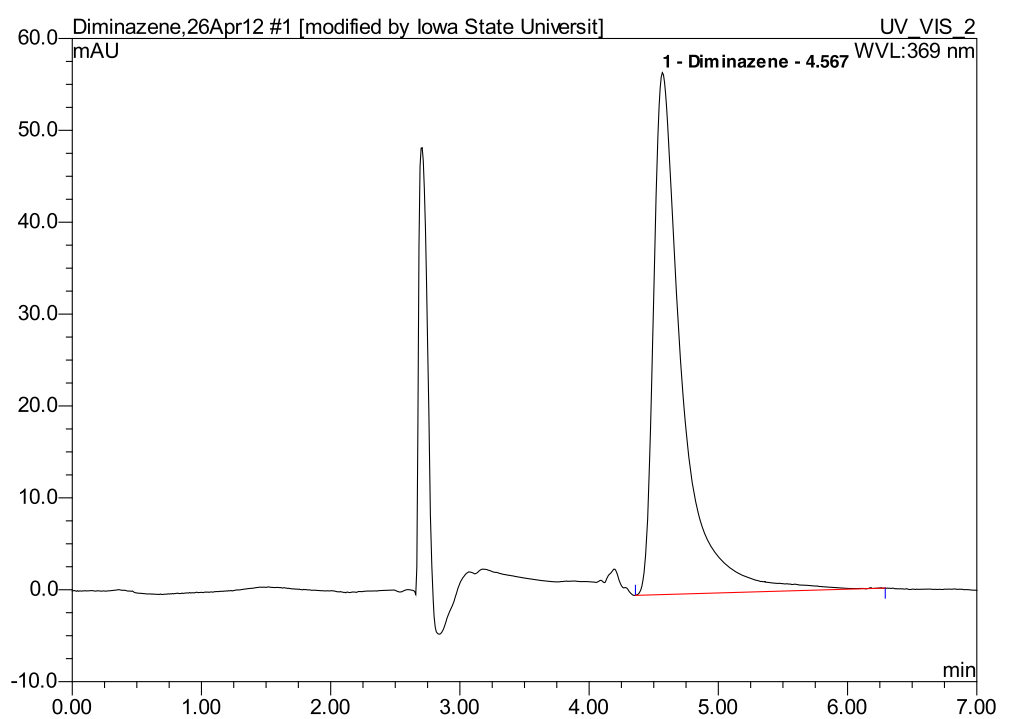

Figure 5 Chromatogram of the standard of diminazene diaceturate

temperatures that are common in the Far North of Cameroon.

Figures 5, 6, 7, 8, 9 show the typical HPLC chromatogram of the standards of diminazene diaceturate, levamisole, oxytetracycline, vitamin $\mathrm{E}$ acetate, and vitamin $A$, respectively, with the retention time and the wavelength.

\section{Organic chemical contaminants}

A Gas Chromatography/Mass Spectrometry (GC/MS) analysis of samples showed that there were no organic contaminants in the oxytetracycline, trypanocide, vitamin and mineral supplement, Fortified Procaine
Penicillin ${ }^{\bullet}$, and parasiticide samples. However, as shown in Figure 10, the total ion chromatogram and mass spectrum of the basic fraction of Pemacain ${ }^{\circledR}$ revealed a suspicious peak matching amiodarone (contaminant) by the NIST library. The identification as amiodarone was not confirmed because a reference standard was not available. Amiodarone is a cardiac drug used in humans and animals, and no explanation could be found for its appearance in this anti-microbial drug sample.

Another molecule was observed in all the fraction samples of Pemacain ${ }^{\bullet}$ and Fortified Procaine Penicillin ${ }^{\odot}$. This molecule, which was absent on the determination of active ingredients by HPLC, was identified as

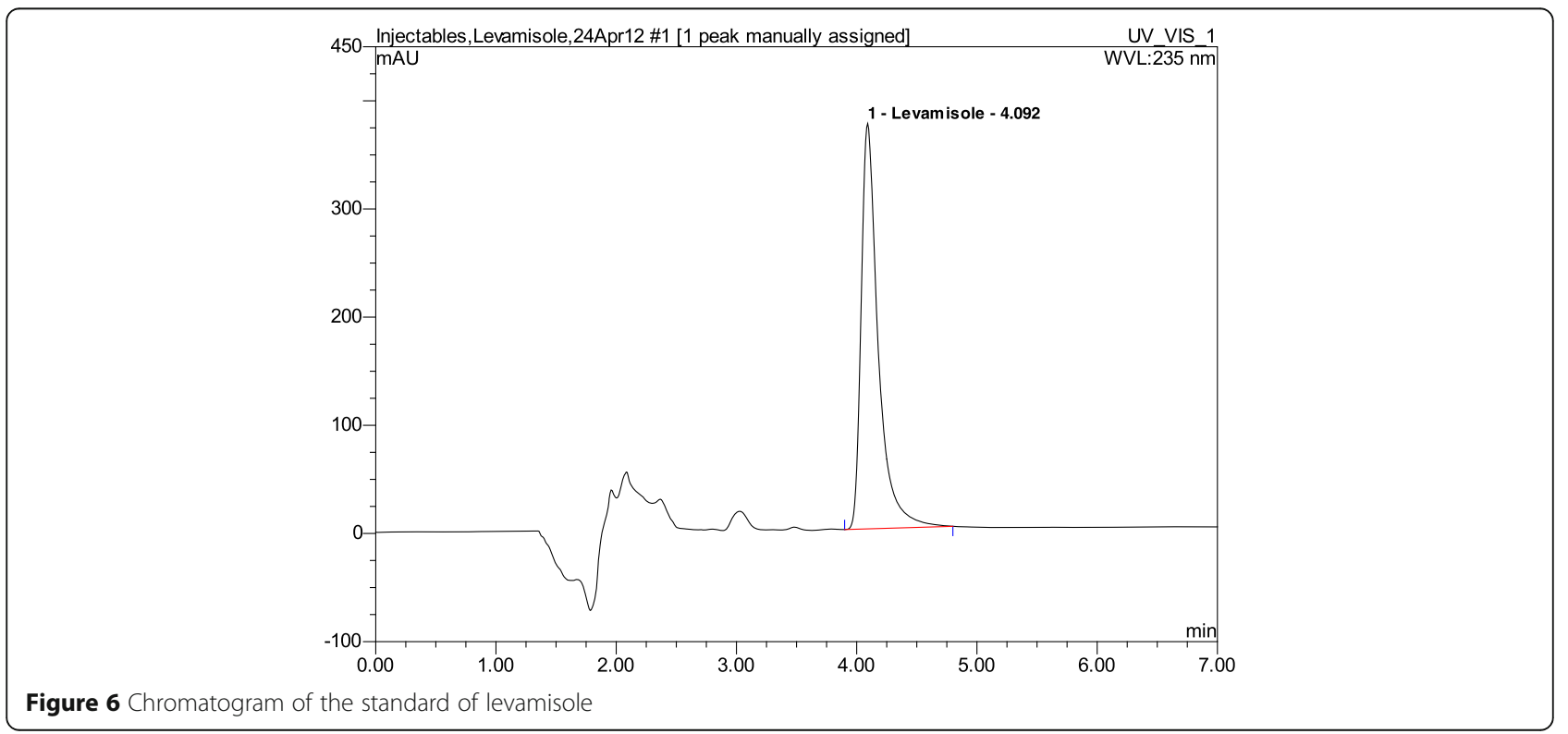




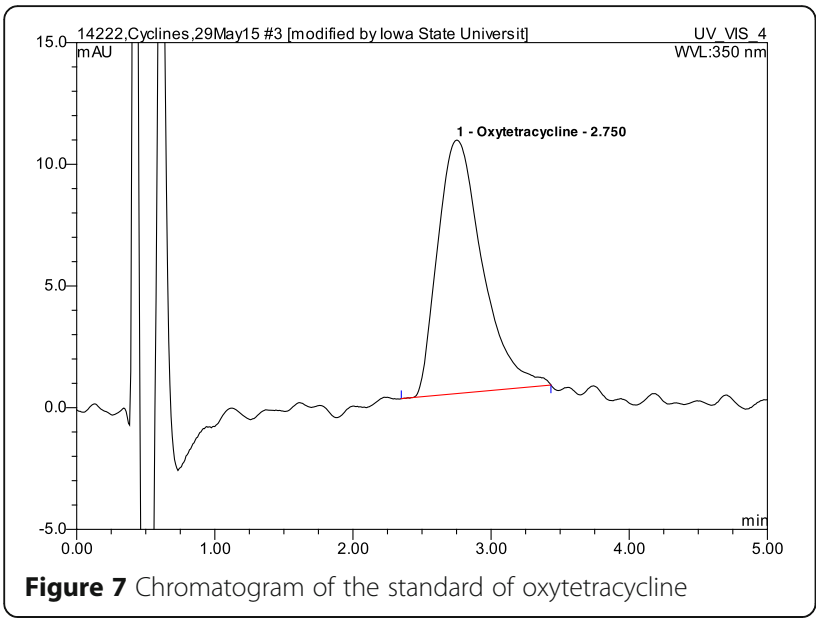

procaine by GC/MS. Thus, procaine may have been present in these samples but at levels too low to detect with HPLC.

\section{Discussion}

Contrary to the findings of other studies (Abiola 2001), we found that the most commonly used medications for treatment of cattle in the Far North of Cameroon are generally of reasonable quality. While the concentrations of active ingredients do not match the label concentrations perfectly, the concentrations are generally close enough that there should be little biological difference from the listed concentration. The only exceptions here are low levels of vitamins and procaine (possibly due to poor storage) and one sample of penicillin, which contained a contaminant that appears to be amiodarone. The percentage of sub-standard quality medications found in this study is lower than the results found by
Têko-Agbo et al. (2008) in all of Cameroon (69\%) and Senegal (67\%) and Abiola (2005) in Chad (61\%). We suggest three possible reasons for the better than expected quality of medications. One, our sample size was small, so we may simply have selected a few good medications that were not representative of all available medications. Two, the recent crackdown on counterfeit medications may have been successful in removing poor quality medications from the markets. Three, though most pastoralists have not studied pharmacology and often cannot read medication labels, they may have learned through trial and error and discussion with other pastoralists which medications are effective. Thus, the most commonly used medications, the ones we selected for testing, may be the best quality medications. As can be seen in the list of medications in Additional file 1, there were many other medications available, but only a few were used by cattle farmers to treat FMD.

This study showed that the majority of pastoralists use veterinary medicines when their cattle have FMD. This result contradicts the hypothesis that, generally, pastoralists used more ethnoveterinary medicine than commercial veterinary drug. This can be explained by the fact that when pastoralists use these drugs, they observe a certain improvement in the health of their animals. In fact, most of the pastoralists reported that, after the use of these drugs, they saw an improvement in the health of their animals. They report that as their reason for continuing to use veterinary drugs. Though initially incongruous to a veterinarian given that FMD is a viral disease with no effective treatment widely available, the apparent effectiveness of these medications can be explained by the presence of co-morbidities,

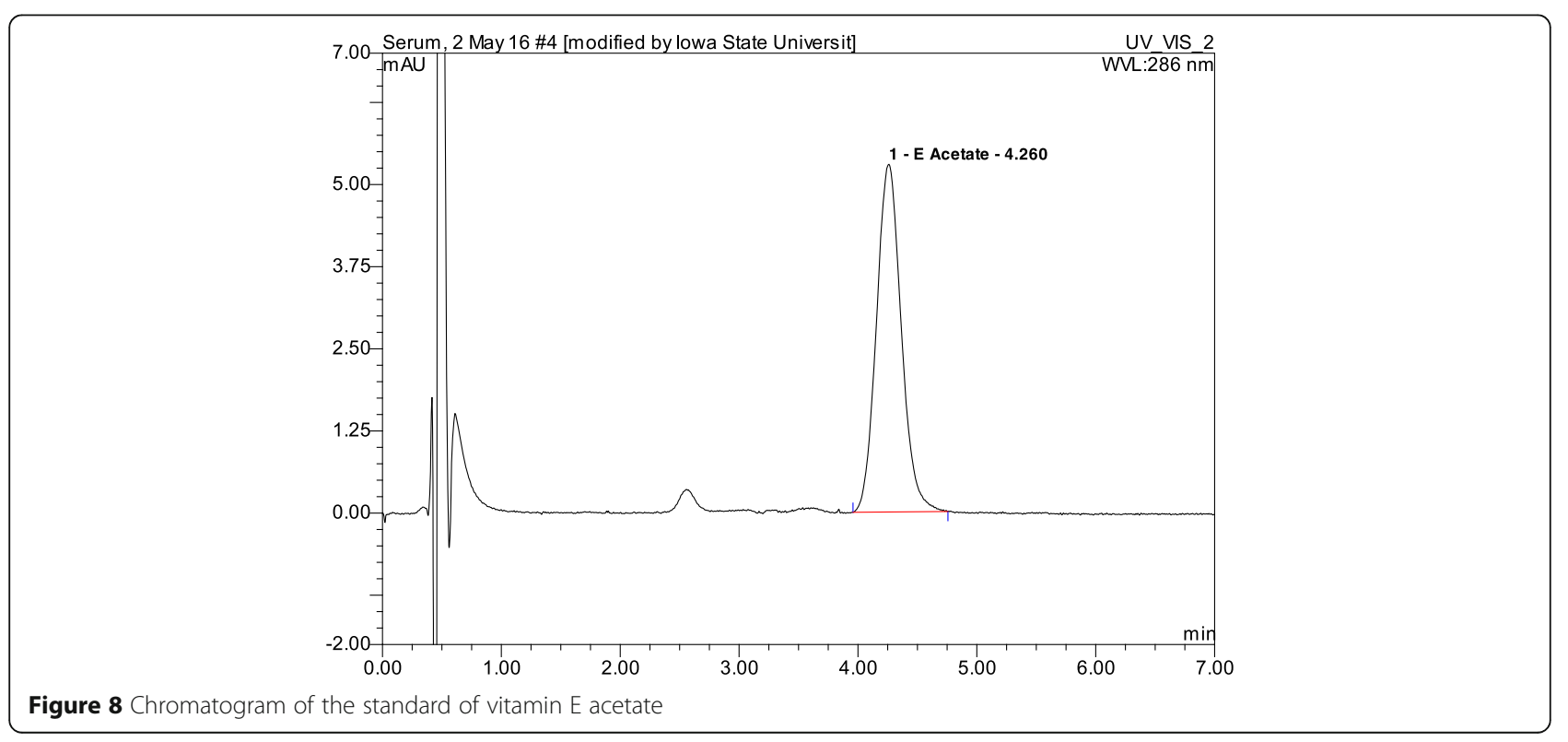




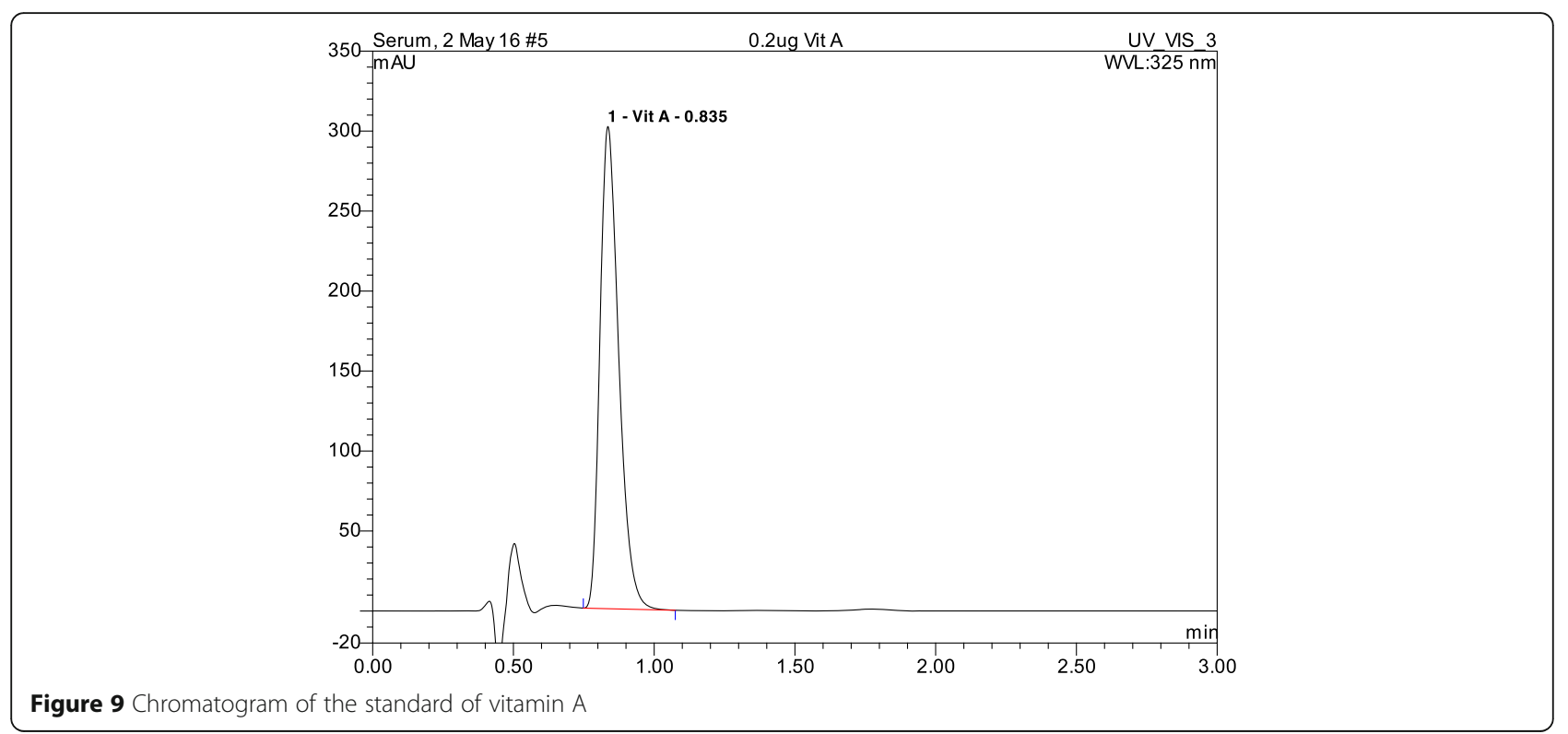

secondary infections, and some misdiagnosis of other febrile and vesicular illnesses as FMD.

Much more concerning than the drug quality or wide use of veterinary medications by pastoralists in the Far North of Cameroon is that, based on our four criteria, we determined that $98 \%$ to $99 \%$ of pastoralists use medications differently than what is recommended by the manufacturers. Though the recommended frequency of administration of the medications and amounts given are relatively consistent with label recommendations (more so for oxytetracycline than penicillin), duration of treatment is respected by less than half of pastoralists for both medications. These medicines are usually provided to pastoralists without prescription, and pastoralists administer these drugs to their animals themselves. Likely, pastoralists have no means of knowing the recommended dosages for medications because most are not literate or are not literate in the language written on the medications (Tomdieu 2013; Vougat 2013). In speaking with pastoralists, they report giving more medication to their cattle because their livestock are very important to them, and they do not wish to let them suffer or die. This result is consistent with that of Messomo (2006) who showed that sometimes cattle herders administer more than the dose indicated so as to see their animals heal quickly or for reasons of economy, they administer low doses. As some of these medications do seem to have lower concentrations of active ingredients than what is listed on their labels, slightly higher than recommended doses may be a logical adjustment. Without further study, we cannot know whether the methods of administration used by pastoralists are actually effective at improving cattle health.
However, the lack of respect for withdraw times most certainly creates drug residues in products that are consumed by people (Kennedy et al. 2000; Shitandi 2004). According to Bousova et al. (2013), these residues of veterinary medicines can endanger the health of consumers. Food products contaminated with drug residues (including anti-microbials) are considered a public health hazard (Chicoine 2007). Also, work done by Avorn et al. (2001) and De Ruyck (2003) showed that anti-microbial misuse is responsible for the emergence of the microbial resistance. So, these residues, as well as shorter than recommended durations of treatment, could cause anti-microbial resistance in animal and human pathogens with adverse effects on animal and human health. Our research team is currently conducting a study to determine the quantity of antibiotic residues in the cattle meat consumed in the Far North of Cameroon.

\section{Conclusions}

While we found little evidence of poor quality medications being used to treat cattle, our survey results showed that pastoralists of the Far North Region of Cameroon used veterinary medicines widely, but did not use them according to label recommendations. Our results revealed that medications (particularly antibiotics) as used by pastoralists could result in sub-therapeutic doses and their use could lead to the persistence and resistance of diseases in this region, with negative consequences for animal and human health. This use of drugs in treatment of food animals may also leave residues in edible tissues and products, which are considered a public health hazard. 


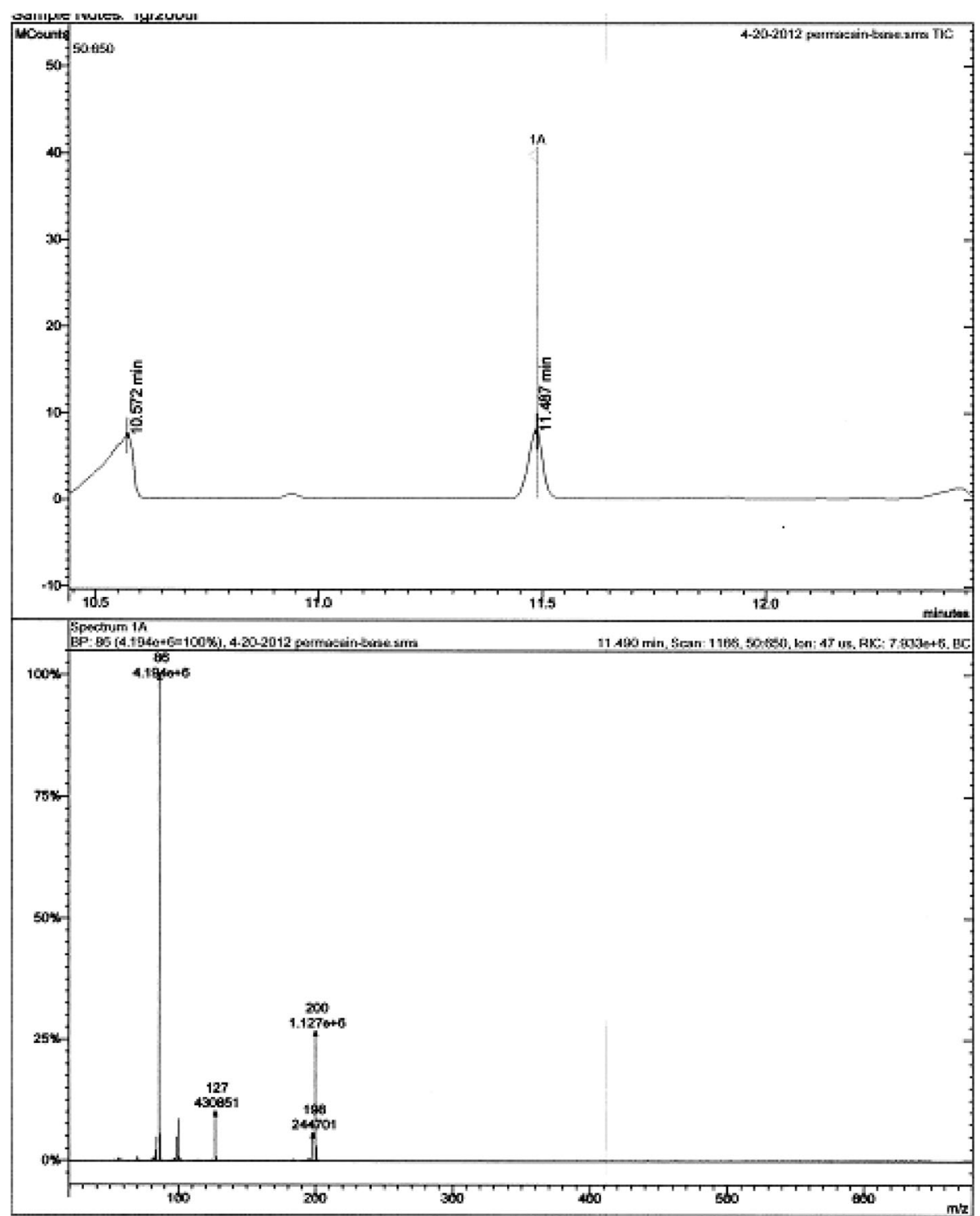

Figure 10 Total ion chromatogram and mass spectrum from the basic fraction of Pemacain ${ }^{\oplus}$ showing a peak that most closely matched amiodarone

In our study area, pastoralists used more commercial veterinary medicine than traditional medicine; however, they tended to use commercial medications in different ways. Unfortunately, much research in pastoralists is focused on traditional ethnoveterinary knowledge, but research focusing on pastoralists' use of commercial veterinary medicine instead of traditional ethnoveterinary medicine could help improve animal and human health in the Far North of Cameroon. Our results demonstrate opportunities for drug manufacturers to improve their labelling with the pastoralist population in mind to improve the efficacy and use of their medications and for the veterinary services of Cameroon to provide information to pastoralists to aid them in using veterinary medications. This sort of information is particularly important for transhumant pastoralists who have little access to veterinary professionals.

\section{Additional file}

Additional file 1: Quality and use of veterinary pharmaceuticals by pastoralists in the Far North Region of Cameroon. (DOC $353 \mathrm{~kb}$ )

\section{Abbreviations}

CARPA: Centre d'Appui à la Recherche et au Pastoralisme; FMD: Foot-andmouth disease; GC/MS: Gas Chromatography/Mass Spectrometry; GIC: Common Initiative Group; HPLC: High-Performance Liquid

Chromatography; MINEPIA: Ministry of Livestock, Fisheries and Animal 
Industries; NIST: National Institute of Standards and Technology; SODECOTON: Société de Développement du Coton

\section{Acknowledgements}

This research was funded by the U.S. National Science Foundation (DEB1015908) via a fellowship from the Disease Ecology and Computer Modeling Laboratory (DECML) of the Ohio State University. The authors express their thanks to the team of the Centre d' Appui à la Recherche et au Pastoralisme (CARPA) for their assistance and the Far North Regional Delegation of the Ministry of Livestock, Fisheries and Animal Industries (MINEPIA) for granting research permission.

\section{Authors' contributions}

The paper is the product of an interdisciplinary collaboration between the University of Maroua (Cameroon), the Veterinary Diagnostic and Production Animal Medicine of lowa State University (USA), and the Disease Ecology and Computer Modeling Laboratory of the Ohio State University (USA). The field work was supervised by the Ohio State team: RBG (veterinary epidemiologist) and MM (anthropologist), and the Cameroonian team: FSH (animal physiologist and pharmacologist), RZ (tropical animal health specialist, veterinarian), and VL (tropical animal health specialist). RRBVN and TT (students) collected and analysed the data. The drug quality testing was overseen by the lowa State team: DES (technician), WKR (veterinary toxicologist), and PMI (clinician), who supervised RRBVN during the laboratory analysis. All authors read and approved the final manuscript.

\section{Authors' information}

RRBVN is currently a Ph.D. Student in the Department of Biological Sciences in the Faculty of Sciences (University of Maroua, Cameroon) focusing on toxicology and pharmacology of medications used to treat cattle in Cameroon. MM is an anthropologist and involved in three longitudinal, transdisciplinary research projects that examine pastoral systems within the analytical framework of coupled human and natural systems. WKR is board-certified in general toxicology, and he is currently investigating the efficacy of cobinamide for treatment of hydrogensulphide-induced neurotoxicity, the development and validation of a tissue-based diagnostic test for aflatoxin B1 in liver and urine, and the cyanotoxin-applied research, diagnostic test methods, and impact of microcystin LR on human health and animal health. RBG is a veterinarian and epidemiologist whose research focuses on applications of mathematical modelling and statistics in the field of transboundary animal diseases.

\section{Competing interests}

The authors declare that they have no competing interests.

\section{Publisher's Note}

Springer Nature remains neutral with regard to jurisdictional claims in published maps and institutional affiliations.

\section{Author details}

'Department of Biological Sciences, Faculty of Sciences, University of Maroua, Maroua, Cameroon. ${ }^{2}$ Department of Agriculture, Livestock and By-Products, The Higher Institute of the Sahel, University of Maroua, Maroua, Cameroon. ${ }^{3}$ The Ohio State University, Columbus, OH, USA. ${ }^{4}$ Veterinary Diagnostic and Production Animal Medicine, College of Veterinary Medicine, lowa State University, Ames, IA, USA.

\section{Received: 19 August 2016 Accepted: 14 February 2017}

\section{Published online: 22 March 2017}

\section{References}

Abiola, F.A. 2001. Qualité des anthelminthiques et des trypanocides au Cameroun (étude préliminaire par sondage limité). Rapport d'expertise, 12. Dakar: Ecole Inter-Etats des Sciences et Médécine Vétérinaires.

Abiola, F.A. 2002a. Qualité des anthelminthiques et des trypanocides en Mauritanie (étude préliminaire par sondage limité). Rapport d'expertise, 13. Dakar: Ecole Inter-Etats des Sciences et Médécine Vétérinaires.

Abiola, F.A. 2002b. Qualité des anthelminthiques et des trypanocides au Mali (étude préliminaire par sondage limité). Rapport d'expertise, 13. Dakar: Ecole Inter-Etats des Sciences et Médécine Vétérinaires.
Abiola, F.A. 2005. Qualité des médicaments prélevés au Tchad. Rapport d'expertise 12. Dakar: Ecole Inter-Etats des Sciences et Médécine Vétérinaires.

Avorn, JL, JF Barrett, PG Davey, SA McEwen, TF O'Brien, and SB Levy. 2001. Antibiotic resistance: Synthesis of recommendations by expert policy group. Alliance for the prudent use of antibiotics. http://www.who.int/csr/resources/ publications/drugresist/antibiotics.pdf. Accessed 1 Mar 2017.

Bousova, K., H. Senyuva, and M. Klaus. 2013. Quantitative multi-residue method for determination antibiotics in chicken meat using turbulent flow chromatography coupled to liquid chromatography-tandem mass spectrometry. Journal of Chromatography A 1274: 19-27.

Chicoine, AL. 2007. An investigation of intraperitoneal procaine penicillin G administration in lactating dairy cows. Thesis for Masters of Science. University of Saskatchewan, Canada. 107p. http://citeseerx.ist.psu.edu/ viewdoc/download?doi=10.1.1.546.6355\&rep=rep1\&type=pdf. Accessed 1 Mar 2017

De Ruyck, H. 2003. Development of confirmatory methods and disposition of some veterinary drugs in food. Thesis for Doctor Applied Biological Sciences. University of Gent. https://biblio.ugent.be/publication/521757/file/1874959. pdf. Accessed 1 Mar 2017.

GESP. 2009. Growth and employment strategy paper: Reference framework for government action over the period 2010-2020. Washington, DC: International Monetary Fund

Grubman, M.J., and B. Baxt. 2004. Foot-and-mouth disease. Clinical Microbiology Reviews 17(2): 465-493.

Kennedy, D.G., A. Cannavan, and R.J. McCracken. 2000. Regulatory problems caused by contamination, a frequently overlooked cause of veterinary drug residues. Journal of Chromatography A 882: 37-52.

Ludi, A., Z. Ahmed, L.W. Pomeroy, S.J. Pauszek, G.R. Smoliga, M. Moritz, S. Dickmu, S. Abdoulkadiri, J. Arzt, R.B. Garabed, and L.L. Rodriguez. 2016. Serotype diversity of foot-and-mouth-disease virus in livestock without history of vaccination in the Far North Region of Cameroon. Transboundary and Emerging Diseases 63(1): e27-e38. doi:10.1111/tbed.12227.

Messomo, FN. 2006. Etude de la distribution et de la qualité des médicaments vétérinaires au Cameroun. Thèse de Doctorat. Ecole Inter-états des sciences et médecine vétérinaires. http://www.memoireonline.com/06/07/478/m_ etude-distribution-qualite-medicaments-veterinaires-cameroun20.html. Accessed 1 Mar 2017.

MIDIMA. 2011. Diagnostic assessment 2008-2009, to update the regional director of planning and development scheme Sustainable Planning (SDRADDT) in the region of the Far North conducted in 2011. Final report (main document) in November 2009. Ministry of Economy, Planning and Development of Territory, 36

Moritz, M., D. Ewing, and R.B. Garabed. 2013. On not knowing zoonotic diseases: Pastoralists' ethnoveterinary knowledge in the Far North Region of Cameroon. Human Organization 72: 1-11.

Njoya, A., D. Bouchel, A.N. Tama, C. Moussa, A. Martrenchar, and L. Letenneur. 1997. Systèmes d'élevage et productivité des bovins en milieu paysan. World Animal Review 89(2): 12-23.

NSI (National Statistics Institute). 2010. Population and social affairs. Cameroon Statistical Yearbook: Part 2. p. 39-62. http://www.statistics-cameroon.org/ downloads/annuaire2010/chap4.pdf. Accessed 1 Mar 2017.

Roderick, S., P. Stevenson, C. Mwendia, and G. Okech. 2000. The Use of Trypanocides and Antibiotics by Maasai Pastoralists. Tropical Animal Health and Production 32:361-374.

Sanders, P. 2007. Veterinary drug residue control in the European Union. Technologija mesa 1(2): 59-68.

Shitandi, A. 2004. Risk factors and control strategies for antibiotic residues in milk at farm level in Kenya. Ph.D Thesis. Sweden: Uppsala University. http://pub. epsilon.slu.se/554/1/Agraria458.pdf. Accessed 1 Mar 2017.

Spickler, R., A.J.A. Roth, J. Gaylon, and J. Lofstedt. 2010. Emerging and exotic diseases of animals, 4th ed. Ames: lowa State University.

Têko-Agbo, A., F.C. Biaou, K. Akoda, P. Faure, and F.A. Abiola. 2003. Contrefaçons et malfaçons de trypanocides à base de diminazène et d'anthelminthiques contenant de l'albendazole au Bénin et au Togo. Revue Africaine de Santé et de Productions Animales 1: 29-47.

Têko-Agbo, A, FN Messomo, L Walbadet, K Akoda, ELH Niang, and FA Abiola. 2008. Quality of veterinary medicinal products in circulation in Cameroon and Senegal. In OIE Conference on Veterinary Medicinal Products in Africa, Dakar, 25-27 March 2008. http://web.oie.int/eng/VETMED08/pdf manuscrits/pdf_anglais/TEKO_fr_2603_Session2_Manuscript.pdf. Accessed 1 Mar 2017. 
Tomdieu, T.D. 2013. Etude de la distribution des médicaments vétérinaires et de leur utilisation par les éleveurs sédentaires dans la Région de l'Extrême Nord du Cameroun. Thèse d'Ingénieur. Institut Superieur du Sahel, Université de Maroua, Cameroun, 108

Vougat, N.R.R.B. 2013. Qualité des médicaments vétérinaires et leurs utilisations contre la fièvre aphteuse par les éleveurs transhumants de la Region de I'Extrême Nord (Cameroun). Thèse d'Ingénieur. Institut Supérieur du Sahel, Université de Maroua, Cameroun, 101.

Vougat, N.R.R.B., H.S. Foyet, R. Ziebe, and R.B. Garabed. 2015. Antioxidant activity and phytochemical constituent of two plants used to manage foot and mouth disease in the Far North Region of Cameroon. Journal of Intercultural Ethnopharmacology 4(1): 40-46.

Yaya A. Genomic polymorphism in mycoplasma mycoides subsp. Mycoides SC applications in molecular epidemiology and validation of a model of subcutaneous inoculation to study the virulence of the strains. PhD thesis. National Polytechnic Institute of Toulouse; 2008. http://ethesis.inp-toulouse.fr/ archive/00000812/01/Yaya.pdf.

Ziébé, R., E. Thys, and R. De Deken. 2005. Analyse de systèmes de production animale à l'échelle d'un canton: cas de Boboyo dans l'Extrême Nord Cameroun. Revue d'Élevage de Médecine Vétérinaires des Pays Tropicaux 58(3): 159-165.

\section{Submit your manuscript to a SpringerOpen ${ }^{\circ}$ journal and benefit from:}

- Convenient online submission

- Rigorous peer review

- Immediate publication on acceptance

- Open access: articles freely available online

- High visibility within the field

- Retaining the copyright to your article

Submit your next manuscript at $\gg$ springeropen.com 